\title{
Are We Having An Ethical Crisis in Computing?
}

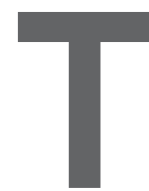

HE COMPUTING FIELD went through a perfect storm in the early 2000s: the dot-com and telecom crashes, the offshoring scare, and a researchfunding crisis. After its glamour phase in the late 1990s, the field seems to have lost its luster, and academic computing enrollments have declined precipitously. This was referred to as the Image Crisis. We seem to be going through another image crisis, of a different nature, these days. Last year the columnist Peggy Noonan described Silicon Valley executives as "moral Martians who operate on some weird new postmodern ethical wavelength." Niall Ferguson, a Hoover Institution historian, described cyberspace as "cyberia, a dark and lawless realm where malevolent actors range." Salesforce's CEO, Marc Benioff, declared: "There is a crisis of trust concerning data privacy and cybersecurity."

Many view this crisis as an ethical crisis. The Boston Globe asserted in March 2018, "Computer science faces an ethics crisis. The Cambridge Analytica scandal proves it!" The New York Times reported in October 2018, "Some think chief ethics officers could help technology companies navigate political and social questions." Many academic institutions are hurriedly launching new courses on computing, ethics, and society. Others are taking broader initiatives, integrating ethics across their computing curricula. The narrative is that what ails tech today is a deficit of ethics, and the remedy, therefore, is an injection of ethics.

This narrative, however, leaves me deeply skeptical. It is not that I am against ethics, but I am dubious of the diagnosis and the remedy. As an example, consider the Ford Model T, the first mass-produced and mass-consumed automobile. The Ford Model $\mathrm{T}$ went into production in 1908 and started the automobile age. With the automobile came automobile crashes, which today kill annually more than $1,000,000$ peo- $^{-}$ ple. But the fatality rate has been going down for the past $100+$ years. Reducing the fatality rate has been accomplished by improving the safety of automobiles, the safety of roads, licensing of drivers, drunk-driving laws, and the like. The solution to automobile crashes is not ethics training for drivers, but public policy, which makes transportation safety a public priority.

Last year I wrote ${ }^{a}$ on how "information freedom" leads Internet companies to use targeted advertising as their basic monetization mechanism, which requires them to collect personal data and offer it to their advertisers. The social scientist Shoshana Zuboff described this business model in 2014 as "surveillance capitalism." There is a direct line between this business model and the 2018 Facebook-Cambridge Analytica scandal, when it was revealed that Cambridge Analytica collected personal data of millions of people's Facebook profiles without their consent and used it for political purposes. We must remember, however, that the advertising-based Internet business is enormously profitable. It is unlikely Internet companies will abandon this lucrative business model because of some ethical qualms, even under Apple's CEO Tim Cook's blistering attack on the "data industrial complex."

The problem with surveillance capitalism is not that it is unethical, but that it is completely legal in many countries. It is unreasonable to expect for-profit corporations to avoid profitable and legal business models. In my opinion, the

a https://bit.ly/2FvmGGt criticism of Internet companies for "unethical" business models is misguided. If society finds the surveillance business model offensive, then the remedy is public policy, in the form of laws and regulations, rather than an ethics outrage. Of course, public policy cannot be divorced from ethics. We ban human-organ trading because we find it ethically repugnant, but the ban is enforced via public policy, not via an ethics debate.

The IT industry has successfully lobbied for decades against any attempt to legislate/regulate IT public policy under the mantra "regulation stifles innovation." In response to the investigation of Tesla's CEO Elon Musk by the U.S. Security and Exchange Commission for possible security-law violation, a recent Wired magazine headline proclaimed, "The case against Elon Musk will chill innovation!" Of course regulation chills innovation. In fact, the whole point of regulation is to chill certain kinds of innovation, the kind that public policy wishes to chill. At the same time, regulation also encourages innovation. There is no question that automobile regulation increased automobile safety and fuel efficiency, for example. Regulation can be a blunt instrument and must be wielded carefully; otherwise, it can chill innovation in unpredictable ways. Public policy is hard, but it is better than anarchy. ${ }^{\text {b }}$

Do we need ethics? Of course! But the current crisis is not an ethics crisis; it is a public policy crisis.

b See Point/Counterpoint debate in the December 2018 issue.

Moshe Y. Vardi (vardi@cs.rice.edu) is the Karen Ostrum George Distinguished Service Professor in Computational Engineering and Director of the Ken Kennedy Institute for Information Technology at Rice University, Houston, TX, USA $\mathrm{He}$ is the former Editor-in-Chief of Communications.

Copyright held by author 